\title{
The effects of silicon and titanium on safflower (Carthamus tinctorius L.) growth under moisture deficit condition
}

\author{
Mohsen JANMOHAMMADI ${ }^{{ }^{*}}$, Nasrin MOHAMMADI ${ }^{1}$, Fariborz SHEKARI ${ }^{1}$, Amin ABBASI $^{1}$, Mohammad $^{2}$ \\ ESMAILPOUR $^{2}$
}

Received June 01, 2017; accepted July 26, 2017.

Delo je prispelo 01. junija 2017, sprejeto 26. julija 2017.

\begin{abstract}
Safflower is one of important crop in semi-arid regions of the world, where the precipitations are limited. In order to investigate the effect of foliar spray of nano-silicon dioxide $(10$ and $20 \mathrm{mM})$ and nano titanium dioxide $(25$ and $50 \mathrm{mM})$ and water-deficit stress (irrigation after $110 \mathrm{~mm}$ evaporation) on growth parameters and yield components of spring safflower a field experiment was carried out at the highland semi-arid region, in, North West of Iran. Water deficit stress significantly reduced morpho-physiological traits such as ground cover, canopy width, leaf fresh mass, leaf are and plant height) as well as yield components (e.g. capitulum diameter, seed mass and seed number per capitulum). However, the plants grown under water deficit condition showed the higher harvest index than well irrigated plants. Comparison of the foliar treatments showed that the both nano-particles (silicon and titanium) improved the plant growth and yield components over the control. However, the effect of nanosilicon was more prominent than titanium. The highest amount of seed oil was recorded under well irrigated condition (irrigation after $60 \mathrm{~mm}$ evaporation) with foliar application of nano-titanium. The percentage of palmitic acid, arachidic acid and myristic acid in seed increased by nano-titanium application. Altogether, principal component analysis indicated that spray of $10 \mathrm{mM}$ nano silicon dioxide was best foliar treatments under all moisture regimes.
\end{abstract}

Key words: safflower; agronomic traits; foliar spraying; nanoparticles; principal component analysis; semi-arid region
IZVLEČEK

\section{UČINKI SILICIJA IN TITANA NA RAST ŽAFRANIKE (Carthamus tinctorius L.) V RAZMERAH POMANKANJA VODE}

Žafranika je pomembna poljščina $\mathrm{v}$ semiaridnih območjih, kjer so padavine omejene. $\mathrm{Z}$ namenom ugotavljanja učinkov pršenja listov $\mathrm{z}$ nano-silicijevim (10 in $20 \mathrm{mM}$ ) in nano titanovim dioksidom ( 25 in $50 \mathrm{mM}$ ) ter stresa zaradi vodnega deficita (namakanje po $110 \mathrm{~mm}$ evaporacije) na rastne parametre in komponente pridelka pomladanske žafranike je bil izveden poljski poskus na višinskem semiaridnem območju severno zahodnega Irana. Vodni deficit je značilno zmanjšal morfološko-fiziološke lastnosti (pokritost tal, širino krošnje, svežo maso listov, listno površino in višino rastlin) kot tudi komponente pridelka (premer koška, maso semen in število semen na košek). Kljub temu so imele rastline, ki so rastle $\mathrm{v}$ razmerah pomanjkanja vode večji žetveni indeks kot dobro namakane. Primerjava foliarnih obravnavanj je pokazala, da so oboji nano delci (silicijevi in titanovi) izboljšali rast rastlin in komponente pridelka $\mathrm{v}$ primerjavi $\mathrm{s}$ kontrolo. Učinek silicijevih nano delcev je bil bolj izražen kot titanovih. Največja vsebnost olja v semenih je bila v dobro namakanih rastlinah (namakanje po $60 \mathrm{~mm}$ evaporacije) $\mathrm{s}$ foliarno dodajanimi nano delci titana. Odstotki palmitinske, arahidonske in miristične kisline $\mathrm{v}$ semenih so se povečali po uporabi nano titanovih delcev. Analiza glavnih komponent je pokazala, da je bilo pršenje z $10 \mathrm{mM}$ nano silicijeva dioksida najboljše foliarno obravnavanje pri vseh vodnih režimih.

Ključne besede: žafranika; agronomske lastnosti; foliarno pršenje; nano-delci; analiza glavnih komponent; semiaridna območja

\footnotetext{
1 Department of Genetic and Plant Production, Faculty of Agriculture University of Maragheh, P.O. Box 55181-83111, Maragheh, Iran; *Corresponding author: jmohamad@alumni.ut.ac.ir

2 Department of Medicinal and Aromatic Plants, Jahrom university, Jahrom, Iran
} 


\section{INTRODUCTION}

The world's population is growing rapidly, so that by 2050 , it is predicted to reach 9.1 billion, $34 \%$ more than today (UN, 2013). Indeed, majority of this population growth is expected to occur in developing countries. These trends refer to the imperative note that, the food security is (and will increasingly continue to be) faced with a major challenge, necessitating anincrease in food production in these areas. However, limited remaining arable lands and restricted water resources bolds the significance of improvingcrop management and implementing strategies to increase drought toleranceto achieve the required massive increase in global food production. Additionally, climate change is one of the main factors restricting the yield, performance and stability of crop production. However, in terms of climate, most of developing countries are located in semi-arid areas which are characterized by highly variable and unpredictable rainfall and total precipitations below potential evapotranspiration, making them frequently engaged with drought stress. However, even at mild intensity, drought stress can inhibit photosynthesis and stomatal conductance significantly, resulting in considerable yield reductions (Shahrokhnia \& Sepaskhah, 2017).

Safflower (Carthamus tinctorius L.) is one of the oldest cultivated crops which is partially adapted to waterdeficit zones. Being a highly branched, herbaceous, thistle-like annual plant, it is commercially cultivated for extracting vegetable oil from its seeds. Besides, safflower is grown for flowers used for coloring, flavoring foods, dyes, medicinal properties, and forage. Safflower can be considered as a promising substitute crop in dryland agro-ecosystems due to its unique agronomic characteristics (Hussain et al., 2016). Safflower is aboriginal to semi-arid environments, and its adaptation to water-deficit conditions is largely resulted from its extended roots which can penetrate to a depth of down to 2 meters to absorb nutrients (HaghighatiMalek \& Ferri, 2014). Nutrient requirements of safflower are similar to those of winter cereal such as wheat and barley, but compared to other annual plants, safflower has a longer growth period. Although the deep rootsystem of safflower allows the plant to utilize nutrients and water from lower depths, its long, dry spell without effective precipitation can negatively affect the seed yield. High evapotranspiration, limited water resources and other parameters in semi-arid regions has invoked the interests for studying the effect of water-deficit stress. Indeed, it is necessary to find or develop appropriate techniques for producing crop under water limited condition (Asadzade et al., 2015). This can be partially reached through growing drought-tolerant varieties while setting forth more rational strategies for exploiting landscape. The use of fertilizers and improving the soil water holding capacity represent other options (Murungweni et al., 2016). Additionally, application of innovative nanotechnologies in agriculture (including the advantageous nano-particles) has been shown to be a promising approach to improve crop production considerably (Lal, 2008; Liu \& Lal, 2015). Ingredients with particle sizes smaller than 100 $\mathrm{nm}$ in at least one dimension are generally classified as nano-materials. A number of engineered nano-materials have been investigated for use in agricultural scope to increase crop productivity and enhance crop protection (Khot et al., 2012). In this regard, foliar application of beneficial nano-particles has opened a new avenue for makingnanotechnology a feasible option in the field.

Among the wide range of inorganic nano-materials introduced recently, silicon $(\mathrm{Si})$ and titanium (Ti) nanoparticles have gained the largest deals of focus. Although silicon is the second most abundant element in the earth's crust (following oxygen), biological role of $\mathrm{Si}$ in plants is yet to be thoroughly studied for specific plants. Being absorbed by plants in the form of silicic acid, siliconis the only nutrient element that is not toxic at high concentrations (Ma et al., 2001; Ma, 2004). Beneficial roles of Si in inducing defense mechanisms under various biotic and abiotic stresses have been reported (Van Bockhaven et al., 2013; Zhu \& Gong, 2014). More interestingly, alleviative effects of Si under water-deficit stress have been observed (Shiet et al., 2016).

Likewise, titanium is the ninth most abundant element in the earth's crust; it is introduced as a beneficial element for plant growth. Nano-titanium dioxide $\left(\mathrm{nTiO}_{2}\right)$ has been reported as an effective photo-catalyst under ultraviolet radiation (Gupta \& Tripathi, 2011). Therefore, leaf-spray of nano titanium dioxide may improve the efficiency of plant photosynthesis and related physiological activities, thereby improvingthe plant growth. Foliar spray of $\mathrm{nTiO}_{2}$ solution on barley under supplemental irrigation conditions may positively affect some morphophysiological characteristics like days to anthesis, chlorophyll content and straw yield (Janmohammadi et al., 2016b). However, there have been reportson possible adverse effects of $\mathrm{nTiO}_{2}$ suspension on corn leaf development and transpiration (Asli \& Neumann, 2009). Also, these authors reposted that, titanium has an inhibitory effect on hydraulic conductivity of roots. Jaberzadeh et al. (2013) showed that, foliar application of low concentrations of $\mathrm{nTiO}_{2} \mathrm{on}$ wheat seedling increased the plant biomass and seed yields under water-deficit stress. These studies supported several earlier studies showing that the response to a nano-material is significantly dependent 
on environmental conditions and plant species (Choi et al., 2003; Zheng et al., 2005; Choi et al., 2010; Mastronardi et al., 2015). Although comparative studies have been carried out on the effects of nano-particles, most studies have been done on cultured samples underartificial conditions, with their applicability to plant responses under natural water-deficit condition remained unclear. The objectives of the present research were: (1) to evaluate foliar application of $\mathrm{nTiO}_{2}$ and nano-silicon dioxide $\left(\mathrm{nSiO}_{2}\right)$ on agronomic traits of safflower in a semi-arid, high-elevation Mediterranean area, (2) to assesschanges in fatty acids under waterdeficit stress, and (3) to identify optimum nano-material and its concentration for safflower.

\section{MATERIAL AND METHODS}

Field experiments were conducted during 2015/16 growing season at the Maragheh Agricultural Research Institute located in a semi-arid area in northwestern Iran. Geographically, the study area was located at $46^{\circ} 16^{\prime}$ Eand $37^{\circ} 23^{\prime} \mathrm{N}$ (altitude $=1485 \mathrm{~m}$ from mean sea level). Based on Koppen's classification, this area has a semi-arid and cold temperate climate with annual precipitation of $375 \mathrm{~mm}$, consisting of $73 \%$ rain and $27 \%$ snow. Total rainfall during the growing season was measured at $97.8 \mathrm{~mm}$. The area is located within Sahand Mountain highs in northwestern Iran, providing itwith very cold winters with minimum air temperatures falling below $-15^{\circ} \mathrm{C}$ and more than 100 days with freezing temperatures. Average maximum and minimum temperatures during the growing season were $21^{\circ} \mathrm{C}$ and $8^{\circ} \mathrm{C}$, respectively.Local soil was clay loam in typeand low in organic carbon $(0.43 \%)$ with a $\mathrm{pH}$ value of 6.85 and total nitrogen and $\mathrm{CaCO}_{3}$ contents of $0.17 \%$ and $19 \%$, respectively. Electrical conductivity (EC) and iron, manganese, copper, zinc, and potassium contents of the soil were measured at $0.84 \mathrm{ds} \mathrm{m}^{-1}, 1.62 \mathrm{ppm}, 6.37$ ppm, 0.49 ppm, 0.73 ppm, and 627 ppm, respectively.

The field was left as fallow for a year before the cultivation. The previous cultivated crop in experimental site was bread wheat. The experimental field was ploughed once in early fall and harrowed twice to bring the soil to fine tilth one week before planting. The recommended dose of fertilizer $(100 \mathrm{~kg}$ of

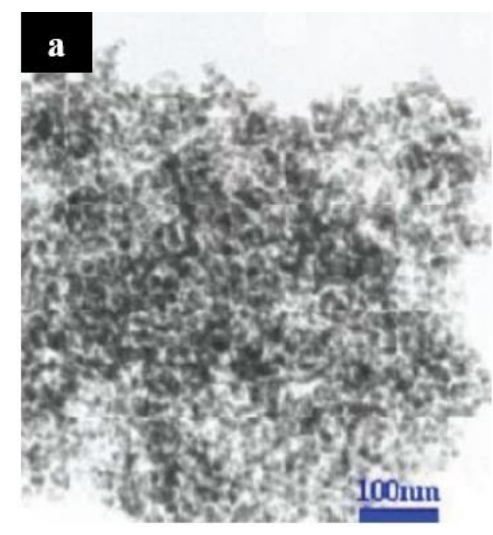

$\mathrm{N}$ and $70 \mathrm{~kg}$ of $\mathrm{P}_{2} \mathrm{O}_{5}$ per hectare) was applied in the form of urea and triple superphosphate at the time of seed bed preparation. The experimental design was factorial on the basis of randomized complete block in three replicates.

The experiments were arranged as split-plot, based on the randomized complete block design with three replications. Two irrigation treatments, namelywell irrigated (W: irrigation after $60 \mathrm{~mm}$ evaporation from class A pan), and water-deficit conditions (S: irrigation after $110 \mathrm{~mm}$ evaporation from class A pan) were assigned to the main plots and suspensions of nanoparticlesat different concentrations were allocated to sub plots. Under water-deficit condition,irrigation gravimetric water content $(\theta \mathrm{g})$ of soil was measured before the irrigation, indicating $16 \%$ to $27 \%$ water content at a depth of $30 \mathrm{~cm}$. The treatments were subjected to foliar application at 5 levels including control (spray of distilled water), $\mathrm{nSiO}_{2}$ (at 10 and 20 $\mathrm{mM}$ ) and $\mathrm{nTiO}_{2}$ (at 25 and $50 \mathrm{mM}$ ). Nanoparticles were purchased from the Pishgaman Nano Co., Iran. According to the manufacturer, particle sizes of the purchased $\mathrm{SiO}_{2}$ ranged within 20-100 nm. Synthesized nanoparticles were characterized morphologically by transmission electron microscopy (Figure 1). According to the results, specific surface area of the nano-sized particles was $180-600 \mathrm{~m}^{2} \mathrm{~g}^{-1}$ at $99.7 \%$ purity.

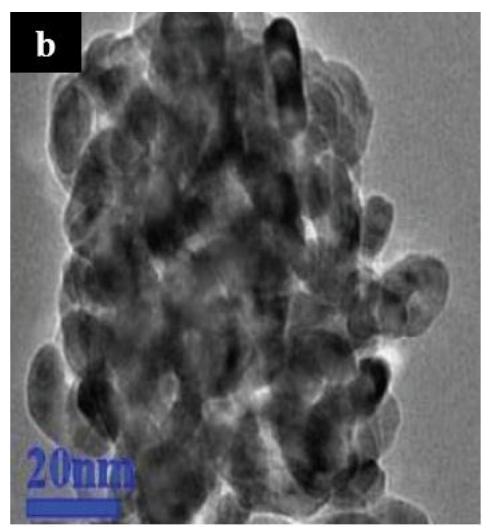

Figure 1: Transmission electron microscopy (TEM) micrograph of synthesized nano-silicon dioxide (a) nanotitanium dioxide (b) 
A productive and thorn-less variant of safflower, locally referred to as 'Golestan', was used in the present study. Before the start of the experiment seed were propagated in isolated fields under full irrigated condition, according to Sabaghnia et al. (2015), in northwest of Iran. Seeds were treated with a mixture of carboxin (5,6-dihydro-2-methyl-1,4-oxathiin-3-carboxamide) and actellic (a.i. pirimiphos methyl) at (2:1) to minimize the probability of seed- and soil-borne diseases. The seedswere sown at $30-\mathrm{cm}$ row spacing in $2.5 \times 6 \mathrm{~m}$ plots $\left(15 \mathrm{~m}^{2}\right)$ using an experimental seed drill, on March $28^{\text {th }}$. All plots were irrigated twice after sowing and subsequent irrigations were applied according to the treatments (W and S) by drip irrigation system. During the irrigations, the plots were irrigated to up to $70 \%$ of field capacity.

All necessary cultural practices and plant protection measures were taken uniformly for all plots during the entire period of experimentation. Weeds were controlled by hand weeding in spring. Nanoparticlesuspensions were applied using an atomizer sprayer. Foliar spray treatments were initiated 40 days after planting and repeated once each 10 days until grain filling stage. Relative water contents were evaluated at the beginning of capitulum formation stage (BBCH scale: 50$)$. Five fresh leaves of the same size and age were collected from five plants from each treatment, and then weighted $\left(F_{M}\right)$. Leaf segments were kept immersed in distilled water for $24 \mathrm{~h}$ at room temperature in the dark. The turgid mass $\left(\mathrm{T}_{\mathrm{M}}\right)$ of the leaves was measured before having the leaves oven-dried at $80{ }^{\circ} \mathrm{C}$ for $72 \mathrm{~h}$ until constant mass and then reweighted $\left(\mathrm{D}_{\mathrm{M}}\right)$. The fresh mass, turgidity, and dry weights of the leaf segments were used to determine hydration and relative water content according to Sangakkara et al. (1996).Accordingly, hydration was determined as $\mathrm{H}(\%)$ $=100-100\left(\mathrm{D}_{\mathrm{M}} / \mathrm{F}_{\mathrm{M}}\right)$ and relative water content (RWC) was determined as RWC $(\%)=\left[\left(\mathrm{F}_{\mathrm{M}}-\mathrm{D}_{\mathrm{M}}\right) /\right.$ $\left.\left(\mathrm{T}_{\mathrm{M}}-\mathrm{D}_{\mathrm{M}}\right)\right] \times 100$. Leaf area was estimated at the end of flowering (BBCH scale: 69).

Non-contact surface temperature of the leaves was measured at early flowering stage $(\mathrm{BBCH}$ scale: 61) using an IR thermometer device (Testo830-T2). Measurements were done on 10 plants per plot. Chlorophyll index was measured on 10 fully expanded leafs of a plant at each plot using a portable chlorophyll meter (SPAD) at capitulum and fruit development stage (BBCH scale: 71). The ground cover was evaluated in terms of the amount of dead plant material covering the soil surface. Average canopy spread was measured as the average horizontal width of the plant canopy, taken from right to left as one moves around the plant. Ground cover and canopy spread were measured during the flowering stage $(\mathrm{BBCH}=65 ; 50 \%$ of florets open in flowers on the main shoot). For eliminating the border effects, lateral rows at both ends of each plot were excluded from the measurements. At maturity stage, the plants were cut at ground level from two middle rows and then oven-dried at $80{ }^{\circ} \mathrm{C}$ until a constant mass was reached. Seeds were separated from straw by crushing. The seed and straw (stem plus leaves) were weighted by a balance and yields were determined per unit area for different treatments. Total biomass was also calculated by summing upsafflower seed and straw. Evaluated agronomic traits were number of branches per plant, stem diameter $(\mathrm{mm})$, capitulum diameter $(\mathrm{mm})$, number of capitula per plant, number of achenes per capitulum, achene mass per capitulum, and thousand-achene mass. Harvest index was calculated as the ratio of achene yield to aboveground dry matter at maturity. Protein and oil contents $(\%)$ of the seeds were measured using a near-infrared seed analyzer (Zeltex). The oil contents of the samples were determined according to Darinkaboud and Gharibi (2016) using soxhlet extraction technique. For this purpose, the seeds were ground in a mill to a particle size of $0.5 \mathrm{~mm}$. Then $500 \mathrm{mg}$ of the seed meal was transferred into a weighed cellulose extraction thimble which was then sealed with cotton wool. The samples were dried in the thimbles (at $60{ }^{\circ} \mathrm{C}$ for $15 \mathrm{~h}$ ) before reweighting the thimbles. The oil was extracted with petroleum ether in a 500-ml soxhlet instrument at $70{ }^{\circ} \mathrm{C}$ for $10 \mathrm{~h}$. Oil contents of the samples were determined after drying and weighing the extracted samples with the thimbles.

Contents of palmiticacid, arachidic acid and myristic acid were evaluated by gas chromatography according to Rudolphi et al. (2012). For this purpose, $200 \mathrm{mg}$ of the seed meal was mixed with $0.5 \mathrm{ml}$ of sodiummethylate. The mixes were then incubated twice in a water bath at $20^{\circ} \mathrm{C}$ for $10 \mathrm{~min}$ and mixed in between the incubation courses. After adding $300 \mu \mathrm{l}$ of $\mathrm{NaHSO}_{4}$ $(5 \%)$ and $300 \mu \mathrm{l}$ of iso-octane to the mix, the sample was centrifuged at $2,000 \mathrm{U} / \mathrm{min}$ for $10 \mathrm{~min}$. Subsequently, $200 \mu \mathrm{l}$ of the upper liquid phase was analyzed by gas chromatographically (Chrompack CP 9001, equipped with a flame ionizing detector).The data was subjected to analysis of variance (ANOVA) using MSTATC statistical package. Differences were compared by Least Significant Difference Test (LSD) at alpha 0.05 . 


\section{RESULTS}

Results of ANOVA showed that, most of the morphophysiological traits were significantly affected by moisture regimes and foliar treatments (Table 1). The main effects of moisture regime and foliar treatment as well as their interaction effects (moisture regime $\times$ foliar treatment) were found to be statistically significant $(\mathrm{p}<0.01)$ for the ground cover percentages. Water-deficit conditions reduced this trait considerably. Assessments of ground cover between different combined treatments revealed that, the highest values were recorded for the plants grown under well irrigated condition and those subjected to foliar application with $25 \mathrm{mM} \mathrm{Ti}, 10 \mathrm{mM} \mathrm{Si}$ and $50 \mathrm{mM} \mathrm{Ti}$, respectively (Figure 2). A parallel trend was also observed for canopy width, wherethe plant treated with the nanoparticles at low concentration showed the widest canopy. The smallest canopy width was, however, recorded for the plants treated with distilled water (control) and $20 \mathrm{mM}$ Si under water-deficit stress.

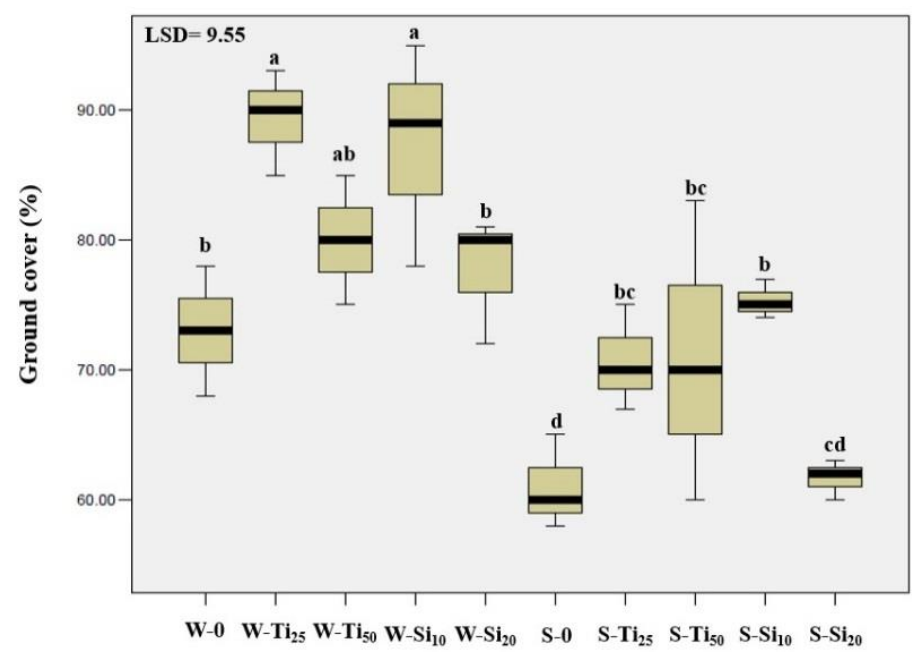

Figure 2: The effect of foliar application of nano-particles on ground cover percentage of safflower plants under different moisture condition. Ti: nano titanium dioxide, Si: nano silicon dioxide, W: well irrigated, S: water deficit condition. The numbers beside the nano-particles refers to the concentration of nanoparticles suspension. Number of zero refers to control conditions (spraying of distilled water). Vertical bars in each column are standard error. Between the columns with different names there are statistically significant differences.

Likewise, assessment of fresh leaf mass showed that this trait has been significantly affected by both moisture regimes and foliar treatments (Table 1). Waterdeficit stress reduced the fresh leaf mass by $33 \%$ in comparison with that under well irrigated condition. A comparison on average fresh leaf mass between the foliar treatments revealed that, the highest mass were those of the plants treated with nano-particle suspensions at low concentration $(10 \mathrm{mM}$ Si and $25 \mathrm{mM}$ Ti). Water-deficit stress was seen to significantly increase the canopy temperature (by up to $2^{\circ} \mathrm{C}$ ), while the plants treated with titanium nano-particles had lower canopy temperatures (Table 1). 
Mohsen JANMOHAMMADI et al.

Table 1: Effect of different moisture deficit stress and foliar application of nano-practices on morpho-physiological traits of safflower (Carthamus tinctorius L.) plants

\begin{tabular}{|c|c|c|c|c|c|c|c|c|c|}
\hline Treatment & GC & $\mathrm{CW}$ & FWL & CT & $\mathrm{PH}$ & RWC & $\mathrm{CHL}$ & LA & $\mathrm{DCE}$ \\
\hline Well irrigated & $81.46 \mathrm{a}$ & $34.61 \mathrm{a}$ & $14.56 \mathrm{a}$ & $26.72 b$ & $58.96 \mathrm{a}$ & $75.00 \mathrm{a}$ & $49.11 \mathrm{a}$ & $666.30 \mathrm{a}$ & $72.13 \mathrm{a}$ \\
\hline moisture deficit & $67.93 b$ & $24.10 \mathrm{~b}$ & $10.88 \mathrm{~b}$ & $28.71 \mathrm{a}$ & $52.42 \mathrm{~b}$ & $64.13 b$ & $49.53 \mathrm{a}$ & $465.78 b$ & $64.06 \mathrm{~b}$ \\
\hline control & $67.00 \mathrm{c}$ & $23.38 \mathrm{c}$ & $8.97 d$ & $28.01 \mathrm{a}$ & $49.10 \mathrm{~b}$ & $65.33 c$ & $42.75 b$ & $464.91 \mathrm{c}$ & $63.33 c$ \\
\hline $\mathrm{Nano}^{-\mathrm{TiO}_{2}} 25 \mathrm{mM}$ & $80.00 \mathrm{a}$ & $34.51 \mathrm{a}$ & $13.85 \mathrm{ab}$ & $27.31 \mathrm{ab}$ & $60.29 a$ & $72.00 \mathrm{a}$ & $53.65 a$ & $557.82 \mathrm{~b}$ & $70.83 \mathrm{ab}$ \\
\hline Nano- $\mathrm{TiO}_{2} 50 \mathrm{mM}$ & $75.50 \mathrm{ab}$ & $27.73 b$ & $11.37 \mathrm{~b}$ & $26.97 b c$ & $54.35 \mathrm{ab}$ & $70.50 \mathrm{ab}$ & $48.14 \mathrm{ab}$ & $537.09 \mathrm{bc}$ & $68.00 \mathrm{ab}$ \\
\hline Nano-SiO ${ }_{2} 10 \mathrm{mM}$ & $81.33 \mathrm{a}$ & $34.67 \mathrm{a}$ & $16.40 \mathrm{a}$ & $27.55 \mathrm{ab}$ & $60.06 \mathrm{a}$ & $73.33 \mathrm{a}$ & $52.56 \mathrm{a}$ & $674.93 \mathrm{a}$ & $72.16 \mathrm{a}$ \\
\hline Nano- $\mathrm{SiO}_{2} 20 \mathrm{mM}$ & $69.66 \mathrm{bc}$ & $26.47 \mathrm{bc}$ & $13.02 \mathrm{bc}$ & $28.75 \mathrm{a}$ & $54.66 \mathrm{ab}$ & $66.66 \mathrm{bc}$ & $49.81 \mathrm{ab}$ & $573.10 \mathrm{~b}$ & $66.16 \mathrm{bc}$ \\
\hline \multicolumn{10}{|l|}{ Level of significance } \\
\hline $\mathrm{S}$ & ** & *** & *** & *** & ** & ** & NS & ** & *** \\
\hline $\mathrm{N}$ & ** & ** & ** & $*$ & $*$ & $* *$ & $*$ & ** & $*$ \\
\hline $\mathrm{S} \times \mathrm{N}$ & ** & *** & NS & NS & NS & * & NS & * & NS \\
\hline
\end{tabular}

GC: ground cover percentage, CW: canopy width $(\mathrm{cm}), \mathrm{FWL}$ : leaves fresh mass $(\mathrm{g}), \mathrm{CT}$ : canopy temperature $\left({ }^{\circ} \mathrm{C}\right), \mathrm{PH}:$ plant height $(\mathrm{cm}), \mathrm{RWC}$ relative water content (\%), CHL: chlorophyll content (SPAD unit), LA: leaf area $\left(\mathrm{cm}^{2}\right)$, DCE: number of day from sowing to capitulum emergence. Different letters within columns indicate statistically significant differences at the $5 \%$ level of significance. S: moisture stress, N: nano-particles, $\mathrm{S} \times \mathrm{N}$ : the interaction effect of nano-particles and stress. NS $=$ Not significant, $*=$ Significant at $5 \%$ level of probability, $* *=$ Significant at $1 \%$ level of probability.

Investigation of plant height indicated that, the waterdeficit regime reduced this trait by $12 \%$ compared with that of well irrigated plants. On the other hand, most of the plants treated with the nano-particles were longer than control plants (treated with distilled water). Investigation of relative water content (RWC) showed that, application of $\mathrm{nTiO}_{2}$ and $\mathrm{nSiO}_{2}$ at low concentration could improve leaf water status under both moisture regimes. However, the positive impact of $10 \mathrm{mM} \mathrm{Si}$ was more prominent than those of other treatments considered. Also, application of $20 \mathrm{mM}$ $\mathrm{nSiO}_{2}$ under water-deficit regimes failed to rectify leaf water statue significantly (Figure 3).
Evaluation of chlorophyll content (SPAD unit) revealed that, the application of nano-particles affected this trait ( $\mathrm{p}<0.05$ ) significantly. Foliar spray of $25 \mathrm{mM}$ Ti, 50 $\mathrm{mM} \mathrm{Ti}, 10 \mathrm{mM} \mathrm{Si}$ and $20 \mathrm{mM} \mathrm{Si}$ could increase the chlorophyll content by $25 \%, 12 \%, 23 \%$ and $16 \%$, respectively, in comparison with control plants (Table 1). Leaf area was seen to be significantly affected by both factors $(p<0.01)$. The largest leaf area was recorded for the plant grown under well irrigated condition with foliar application of $10 \mathrm{mM} \mathrm{Si}$, while the lowest value was recorded for the plants grown under water-deficit condition without nano-particles application or those treated with $25 \mathrm{mM}$ Ti.

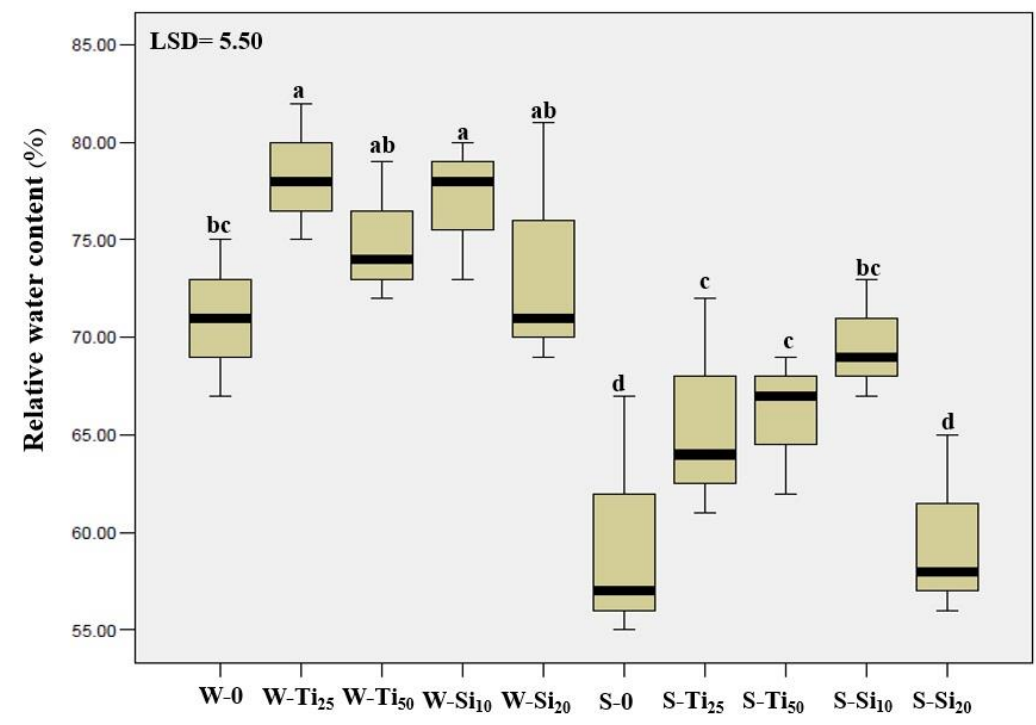

Figure 3: Mean comparison of relative water content of safflower leaves under different foliar treatment with nanoparticles and moisture regimes 


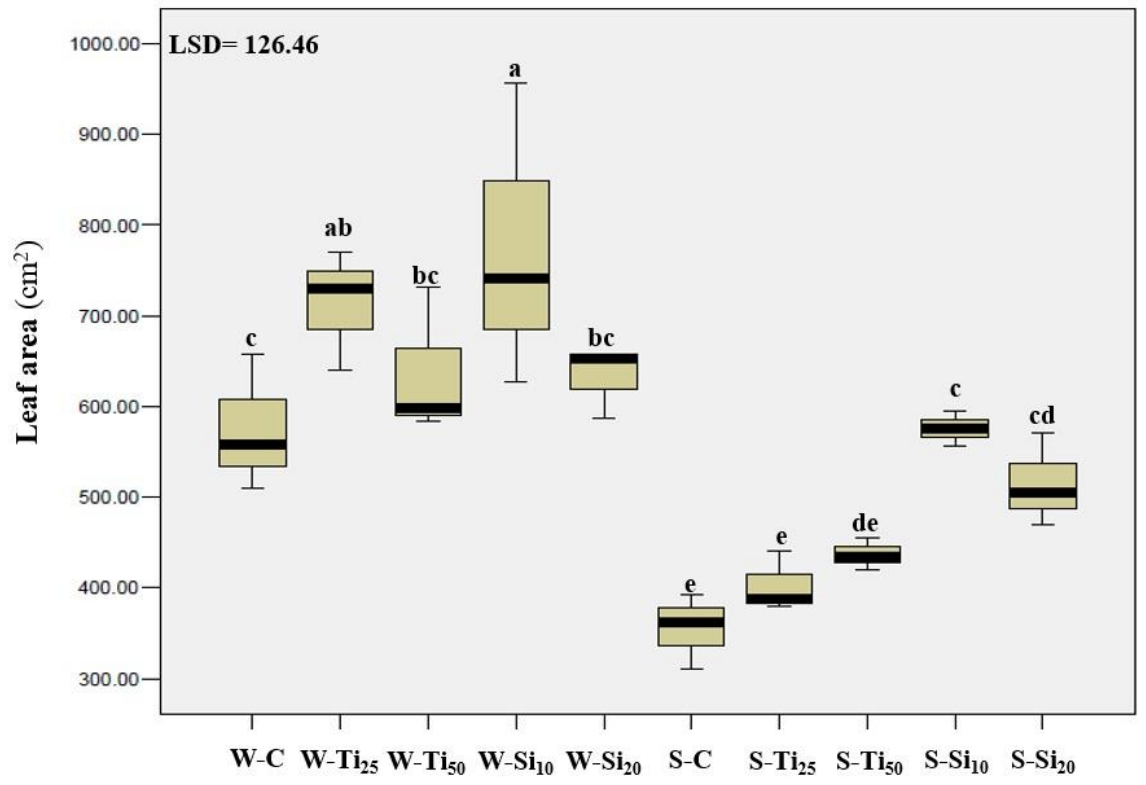

Figure 4: The impact of foliar spray of different nano-particles on leaf area of safflower plants under different moisture regimes

A glancing comparison between the two moisture regimes showed superior positive effects of $\mathrm{n}-\mathrm{TiO}_{2}$ under well irrigated condition (Figure 4). Phenological development was also seen to be affected by moisture regimes, so that the plant grown under water-deficit condition reached capitulum emergence stage way earlier. On the other hand, foliar application of the nano-particles delayed the developmental stage considerably, as compared to control plants (Table 1).

The effects of moisture regimes and foliar treatments on yield componentsare shown in Table 2. Investigation of mean capitulum diameter showed that, the water-deficit stress reduced this trait by $18 \%$ in comparison with that under well irrigated condition. The largest capitulum was recorded for plants treated with $25 \mathrm{mM} \mathrm{Ti}$ and 10 $\mathrm{mM} \mathrm{Si}$, while the smallest one was of control plants and those treated with $20 \mathrm{mM}$ Si. Number of the capitula per plant exhibited a significant decrease under waterdeficit stress. Accordingly, this parameter responded to foliar spray positively, so that the application of Si and Ti suspensions at low concentration could increase this yield component slightly $(\mathrm{p}<0.01)$.

Table 2: Mean comparison of yield and yield components of Safflower (Carthamus tinctorius L.) as affected by irrigation levels and nano-particles

\begin{tabular}{|c|c|c|c|c|c|c|c|c|c|}
\hline Treatment & $\mathrm{MCD}$ & $\mathrm{NCP}$ & TSW & $\mathrm{SNC}$ & SY & BY & $\mathrm{HI}$ & PRO & OIL \\
\hline Well irrigated & $29.66 a$ & $7.46 \mathrm{a}$ & $39.20 \mathrm{a}$ & $29.53 a$ & $1268.53 \mathrm{a}$ & $5011.00 \mathrm{a}$ & $25.44 \mathrm{~b}$ & $13.90 \mathrm{~b}$ & $30.74 \mathrm{a}$ \\
\hline moisture deficit & $25.26 \mathrm{~b}$ & $6.88 \mathrm{~b}$ & $32.33 b$ & $23.17 \mathrm{~b}$ & $958.17 \mathrm{~b}$ & $3521.66 \mathrm{~b}$ & $27.26 \mathrm{a}$ & $19.29 \mathrm{a}$ & $26.31 b$ \\
\hline control & $23.47 \mathrm{c}$ & $6.13 \mathrm{bc}$ & $34.05 b$ & $24.49 \mathrm{c}$ & $1058.33 c$ & $4204.33 \mathrm{ab}$ & $25.36 \mathrm{~b}$ & $18.82 \mathrm{a}$ & $25.44 \mathrm{c}$ \\
\hline $\mathrm{Nano}^{-\mathrm{TiO}_{2}} 25 \mathrm{mM}$ & $31.70 \mathrm{a}$ & $8.00 \mathrm{a}$ & $38.20 \mathrm{a}$ & $28.99 \mathrm{a}$ & $1156.66 \mathrm{ab}$ & $4547.00 \mathrm{a}$ & $25.72 b$ & $16.42 b$ & $32.32 \mathrm{a}$ \\
\hline Nano $-\mathrm{TiO}_{2} 50 \mathrm{mM}$ & $25.98 \mathrm{bc}$ & $6.80 \mathrm{~b}$ & $33.67 \mathrm{~b}$ & $25.76 b c$ & $1055.00 \mathrm{c}$ & $4068.33 \mathrm{a}$ & $26.39 \mathrm{ab}$ & $14.38 \mathrm{c}$ & $30.07 \mathrm{a}$ \\
\hline Nano $-\mathrm{SiO}_{2} 10 \mathrm{mM}$ & $30.38 \mathrm{ab}$ & $8.13 \mathrm{a}$ & $38.04 \mathrm{a}$ & $27.25 \mathrm{ab}$ & $1224.06 \mathrm{a}$ & $4289.33 \mathrm{ab}$ & $28.66 \mathrm{a}$ & $17.54 \mathrm{a}$ & $26.81 \mathrm{c}$ \\
\hline Nano $-\mathrm{SiO}_{2} 20 \mathrm{mM}$ & $25.78 \mathrm{bc}$ & $6.82 \mathrm{~b}$ & $34.85 \mathrm{~b}$ & $25.26 \mathrm{bc}$ & $1071.33 \mathrm{c}$ & $4225.66 \mathrm{ab}$ & $25.62 \mathrm{~b}$ & $15.82 \mathrm{bc}$ & $28.01 \mathrm{~b}$ \\
\hline \multicolumn{10}{|l|}{ Level of significance } \\
\hline $\mathrm{S}$ & * & $*$ & $* *$ & $* *$ & *** & ** & $*$ & $* *$ & $* *$ \\
\hline $\mathrm{N}$ & $*$ & $*$ & $* *$ & $*$ & $* *$ & $* *$ & $*$ & $* *$ & $*$ \\
\hline $\mathrm{S} \times \mathrm{N}$ & NS & NS & $*$ & NS & NS & $* *$ & NS & NS & $*$ \\
\hline
\end{tabular}

MCD: mean capitulum diameter (mm), NCP: number of capitula per plant, TSW: thousand seeds mass (g), SNC: number of seed per capitulum, SY: seed yield $\left(\mathrm{kg} \mathrm{ha}^{-1}\right), \mathrm{BY}$ : biological yield $\left(\mathrm{kg} \mathrm{ha}^{-1}\right)$, HI: harvest index (\%), PRO: seed protein content (\%), OIL: seed oil content (\%; Soxhlet) .Different letters within columns indicate statistically significant differences at the $5 \%$ level of significance. S: moisture stress, N: nano-particles, $\mathrm{S} \times \mathrm{N}$ : the interaction effect of nano-particles and stress. NS = Not significant, $*=$ Significant at $5 \%$ level of probability, $* *=$ Significant at $1 \%$ level of probability.

Evaluation of thousand-seed mass revealed that moisture regime-foliar treatmentinteraction effect was statistically significant at $95 \%$ confidence level.
Significantly lower seed mass (by $21 \%$ ) were observed under water-deficit stress conditions. The heaviest seeds were those of the plants grown under well irrigated 
condition and treated with $\mathrm{Si}$ and $\mathrm{Ti}$ suspensions at low concentration, while the smallest seeds were recorded for the plants grown under water-deficit stress and sprayed with $50 \mathrm{mM}$ Ti and $20 \mathrm{mM} \mathrm{Si}$ (Figure 5).

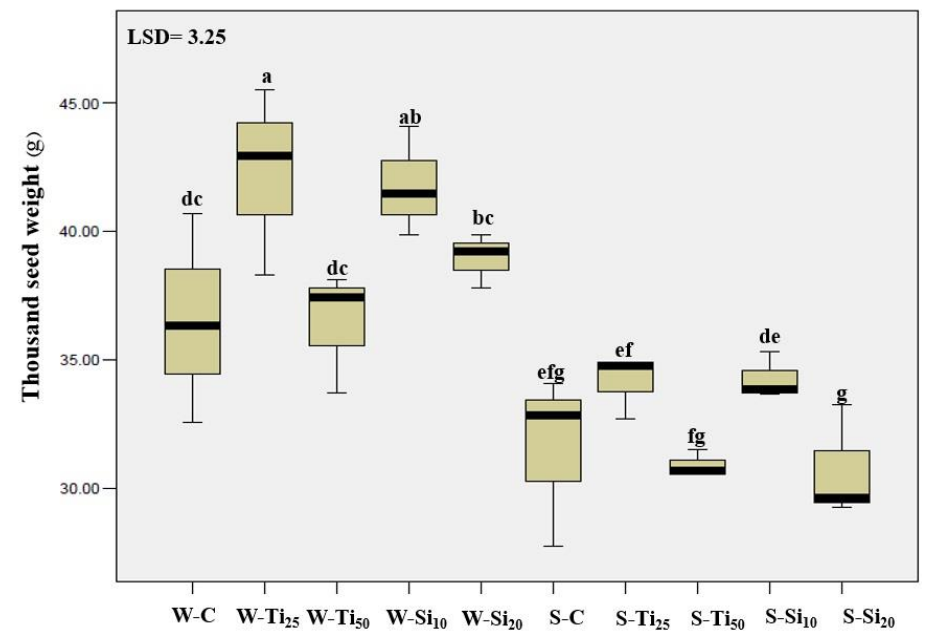

Figure 5: Mean comparison of thousand seed mass in safflower plants under different foliar treatment with nanoparticles and moisture regimes

As one of the most important yield indicators, number of seeds per capitulum decreased noticeably under water shortage (by 27\%). Furthermore, foliar treatment affected the number of seeds per capitulum at $95 \%$ confidence level $(\mathrm{p}<0.05)$, so that the largest number of seeds was recorded for the plants treated with $25 \mathrm{mM} \mathrm{Ti}$ suspension.

Results showed that, water-deficit stress could reduce the seed yield by $32 \%$, as compared to that under well irrigated condition. Also, seed yield responded to foliar treatments significantly, so that the application of 10
$\mathrm{mM} \mathrm{Si}$ increased the seed yield by $15 \%$ over the control plants. All by all, the highest seed yield was obtained by applyingSi and $\mathrm{Ti}$ suspensions at low concentration. Furthermore, the results showed that, water scarcity tends to reduce the biological yield considerably (by $42 \%$ ). A comparison on average values for combined treatments showed that, the highest biological yield was related to the plant grown under well irrigated condition with foliar application of 25 $\mathrm{mM} \mathrm{Ti}$, while the lowest yield was recorded for the plant grown under water-deficit condition with foliar application of $50 \mathrm{mM}$ Ti (Figure 6).

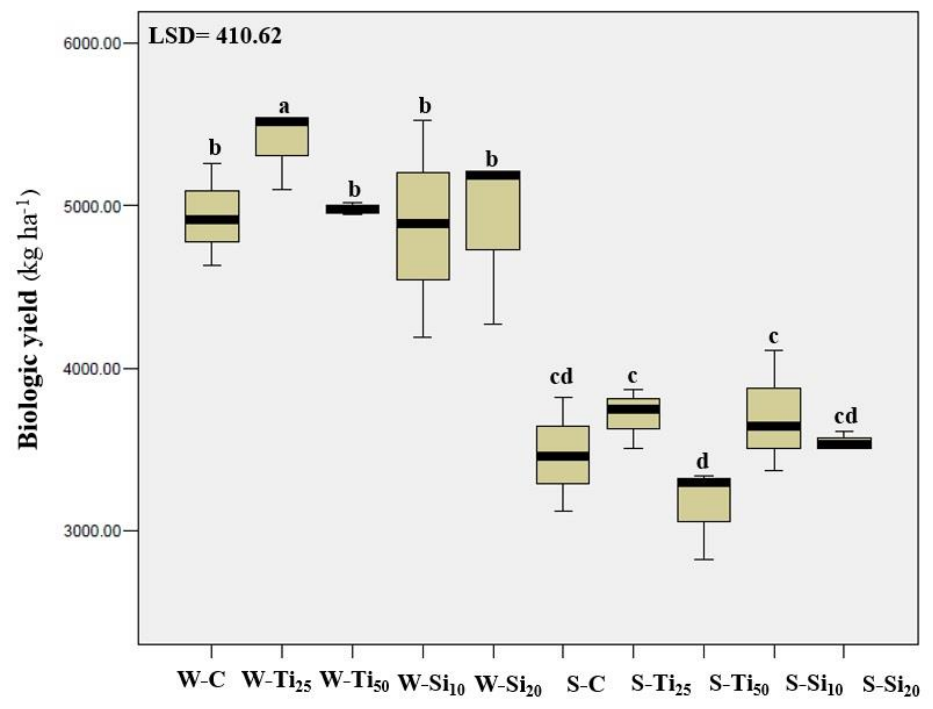

Figure 6: The impact of foliar treatment with different nano-particles on biological yield of safflower plants under different moisture regimes 
Interestingly, water-deficit stress increased the harvest index by $7 \%$ in comparison to that under well irrigated condition. Also foliar application of $10 \mathrm{mM}$ Si increased the harvest index by $13 \%$ over the control plants. The first component in principal component analysis (PCA) clearly separated moisture regimes, with the second component revealingthe statistical distinction of foliar application of $10 \mathrm{mM} \mathrm{Si}$ from other spray treatments under well irrigated condition (Figure 7). Similarly, PCA showed that, although there is no significant difference between foliar treatments under water-deficit stress, application of nano-particles at low concentration
(10 $\mathrm{mM} \mathrm{Si}$ and $25 \mathrm{mM} \mathrm{Ti}$ ) tends to outperform other treatments.

Evaluation of quantitative traits also revealed that, even though most of these parameters were affected by both factors, the responseswere somewhat different for quantitative traits. Water scarcity resulted in a considerable increase in seed protein percentage (Table 2). On the other hand, evaluation of the effect of foliar treatments on seed protein content reveled that, all treatments, except for $10 \mathrm{mM} \mathrm{Si}$, reduced this parameter significantly.

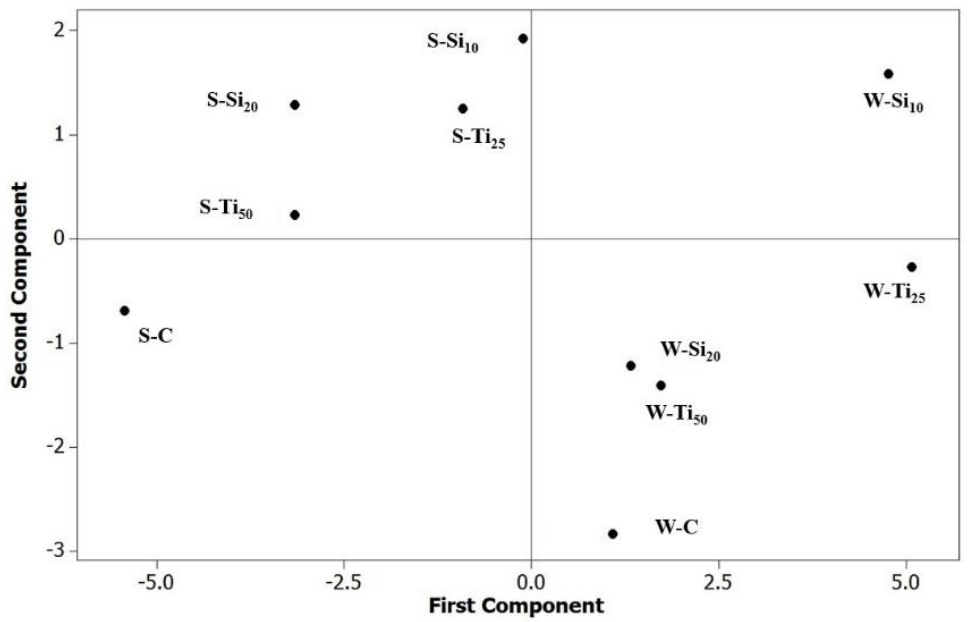

Figure 7: Principal component analysis (PCA) of combined treatments (moisture regimes and nano-particles foliar application) in safflower plants. Ti: nano titanium dioxide, Si: nano silicon dioxide, W: well irrigated, S: water deficit condition. The numbers beside the nano-particles refers to the concentration of nano-particles suspension. Number of zero refers to control conditions (spraying of distilled water).

However, water-deficit stress reduced the seed oil content most intensively (Table 2). Although foliar spray improved the oil contentin general terms, the greatest increase was seen to be related to the application of Ti. Moreover, fatty acid profiles of safflower seed oils revealed that these component were significantly affected by moisture regimes and foliar treatments (Figure 8). Noticeably lower palmitic acid content was seen in water shortage. On the other hand, foliar application of $\mathrm{nTiO}_{2}$, regardless of the concentration, under well irrigated condition resulted in the highest level of palmitic acid. Adverse effects of water shortage on arachidic acid and myristic acid contents were more prominent than that on palmitic acid content (Figure 8). However, the response of arachidic acid to foliar treatments was largely similar to that of palmitic acid, where the highest fat acid content was obtained by foliar application of $50 \mathrm{mM}$ Ti. All by all, the effect of foliar treatment under well irrigated condition was more distinguished on arachidic acid and palmitic acid contents, rather than meristic acid content. 


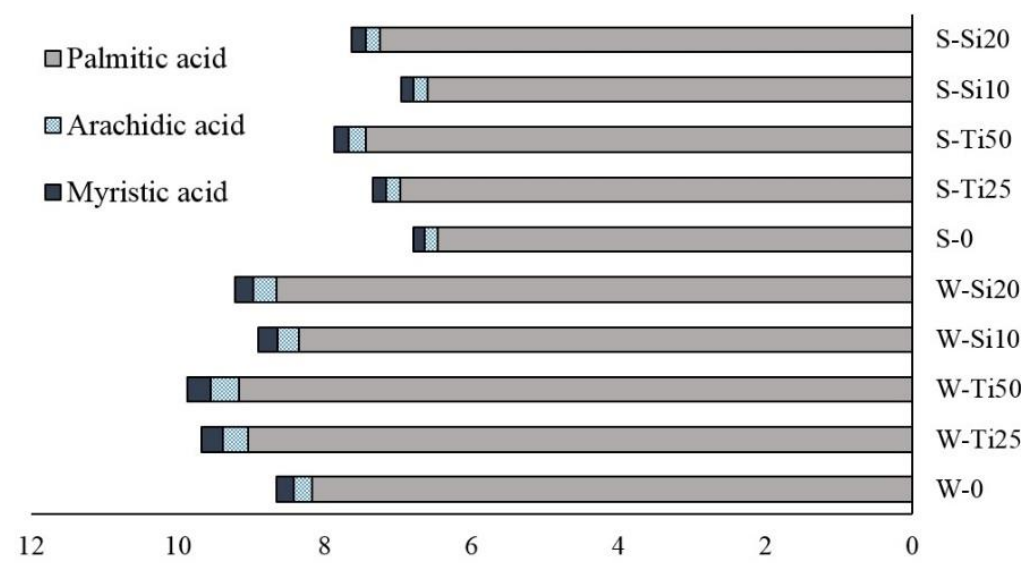

Percentage of total oil

Figure 8: A stacked bar chart which display the change of fatty acids between the combined treatments. Ti: nano titanium dioxide, $\mathrm{Si}$ : nano silicon dioxide, $\mathrm{W}$ : well irrigated, $\mathrm{S}$ : water deficit condition. The numbers beside the nano-particles refers to the concentration of nano-particles suspension. Number of zero refers to control conditions (spraying of distilled water)

\section{DISCUSSION}

It was found that water-deficit stress in the semi-arid region reduced plant growth and seed yield considerably. On the other hand, foliar application of $\mathrm{TiO}_{2}$ and $\mathrm{SiO}_{2}$ nano-particles could significantly affect the evaluated traits. Although the effects of nanoparticles were more obvious under well irrigated condition, low concentrations of $\mathrm{SiO}_{2}$ nano-particles could significantly improve some of crucial agronomic traits such as ground cover percentage. As a very essential attribute of spring crop in a semi-arid region, fast canopy closure may affect the economic yield extensively. In Mediterranean semi-arid areas, precipitation regime is anticipated to be dominated by low, erratic and unpredictable rainfalls. The moisture supplied to the soil from rain is mostly lost by evaporation. Fast canopy closure and a high percentage of ground cover under the Mediterranean conditions may provide numerous benefits. Extended canopy can improve the capturing and use of solar radiation for photo-assimilate synthesis throughout rainy spring months (Soleimanzadeh \& Gooshchi, 2012). Also, quick ground covering can reduce the moisture loss through evaporation and increase competitive power of plant against weeds. This also accords with our earlier observations which showed that, canopy width and ground cover percentage are significantly affected by foliar application of $\mathrm{SiO}_{2}$ nano-particles (Janmohammadi et al., 2016b).

On the contrary, if the nanoparticles show a good translocation through the phloem, the application should be done via foliar spraying. In addition, the nanomaterials moving along the phloem are likely to be accumulated in the plant organs which may act as sink, such as seeds. The beneficial effects of Si have been thought to be due to the precipitation of amorphous silica in plants, which acts as a protectant. As a physicomechanical barrier, nano-silicon can protect plants against biotic and abiotic stresses (Ma, 2004). Nanosilicon can boost plant's defense mechanismsincluding the accumulation of lignin, phenolic compounds, and phytoalexins (Ma \& Yamaji, 2006). Nano-silicon can also deposit on the walls of epidermis and vascular tissues of the stem and leaf surface in most plants; it further controls physiological properties of plants. Also during the pathogenic attack, Si can induce rapid and extensive defense mechanisms (Fauteux et al., 2005). From a physiological standing point, silicon is able to increase the plasma membrane integrity by providing more stable lipids involved in cell membrane (Sahebi et al., 2015). Previous studies have suggested that, application of nano-silicon may alleviate the adverse effects of environmental stress on plants, increasingtheir water-use efficiency and photosynthesis rate (Ma, 2004). It has been suggested that, exogenous silicon may improve plant growth by enhancing antioxidant defense (Karimi and Mohsenzadeh, 2016). Nano-Si can also reduce grazing-resulted damages, such as that by insects, through changes in the tissue level to reduce palatability. Compared to control, treated plants with $\mathrm{Si}$ maintained higher stomatal conductance, relative water content, and higher water potential. Also, their leaves 
were larger and thicker, thereby limiting the loss of water through transpiration (Hattori et al., 2005) and reducing water consumption (Eneji et al., 2008). Si further affects the root structure and improves root resistance in dry soils (Hattori et al., 2005). It has been observed that, $\mathrm{Si}$ increased antioxidant defense capabilities and therefore maintained physiological processes such as photosynthesis (Pei et al., 2010).

The results demonstrated that, the low concentration of nano-particles could simultaneously increase the leaf area, chlorophyll concentration, and seed yield components. Within a plant, the source is the photosynthesizing tissue or the organ exportingcarbon skeletons, the sink is the one requiring carbon feed, the sink strength is the ability of a tissue or an organ to mobilize photo-assimilates, the sink size is the capacity of a tissue or organ to import and store further compounds from the source(s), and the sink activity is measured by the rate of respiration. Our findings revealed that, both of the moisture regimes and foliar treatments affected the source-sink relation considerably. Water scarcity was seen to reduce source and sink sizes significantly, while increasing the sink strength. Water stress increased the seed protein content noticeably. Seed protein was resulted from protein degradation in source tissue and amino acid remobilization for the seed. Available soil, water, temperature, nutrients, light, and $\mathrm{CO}_{2}$ are indubitably important drivers of plant growth (Pessarakli, 2014). The former three (water, temperature, and nutrients) are, however, fundamentally different from the latter two (light and $\mathrm{CO}_{2}$ ) because they can affect both sink and source activities, while light and $\mathrm{CO}_{2}$ can only affect the source activity (Fatichi et al., 2014). It seems that, foliar application of nano-particles increases the plant growth and seed yield through improving the function of photosynthetic apparatus (source activities) and photoassimilate translocation.These results are consistent with those of other studies and suggest thatthe application of $\mathrm{Si}$ may represent an approach to improve the growth of this crop and increase its production in arid or semi-arid areas where water is at a premium;this technique, however, would not fully substitute for an adequate water supply (Kaya et al., 2006).

However, in some of the evaluated traits, especially qualitative aspects and canopy temperature, the application of $\mathrm{nTiO}_{2}$ ended up with better results. The main reason for the improvements of these traits could have been the photo-sterilization and photo-generation of "active oxygen (e.g. superoxide) and hydroxide anions" by $\mathrm{n}-\mathrm{TiO}_{2}$ that could increase the plant stress resistance and promote efficiency of stomatal conductivity (Zheng et al., 2005). $\mathrm{nTiO}_{2}$ increases plant growth by enhancing nitrogen metabolism (Yang et al., 2006) which improves the absorption of nitrate in spinach, and also by accelerating the conversion of inorganic nitrogen into organic nitrogen which increases the fresh and dry masses. Morteza et al. (2013) suggested that foliar utilization of $\mathrm{nTiO}_{2}$ can improve plant growth and grain yield by improving the biosynthesis of pigments and conversionof light energy to chemical energy, thereby increasing photosynthetic efficiency. Effects of $\mathrm{nTiO}_{2}$ on the content of light harvesting complex II (LHC II) on thylakoid membranes of spinach increases LHC II content (Hong et al., 2005; Lei et al., 2007). These promote energy transfer and oxygen evolution in photosystem II (PS II) of spinach (Lei et al., 2007). It was found that, nanoanatase $\mathrm{TiO}_{2}$ promotes antioxidant stress by decreasing the accumulation of superoxide radicals, hydrogen peroxide, and malonyl dialdehyde content while enhancing the activities of superoxide dismutase, catalase (ascorbate peroxidase), and guaiacol oxidase, thereby increasing the evolution oxygen rate in spinach chloroplasts under UV-B radiation (Lei et al., 2008).. Khot et al. (2012) concluded that, the nano size of $\mathrm{TiO}_{2}$ might have increased the absorption of inorganic nutrients, accelerated the breakdown of organic substances, and also caused quenching of oxygen free radicals formed during the photosynthetic process, hence increasing the photosynthetic rate. This finding supports our previous research which showed that foliar application of $\mathrm{nTiO}_{2}$ on barley plants in a semi-arid region positively affected growth rate and seed yield (Janmohammadi et al., 2016a). It seems that, $\mathrm{nTiO}_{2}$ plays a significant role in activatingdefense mechanism and modulating biosynthesis of phytohormones such as cytokinins and gibberellin (Mandeh et al., 2012). However, the accumulation of the nano-particles in plant tissue can be very important point from food safety perspective, therefore; their measurement in future experiments can be very valuable and provide precious information.

\section{CONCLUSION}

Our examination of the effects of $\mathrm{SiO}_{2}$ andTiO2 nanoparticles on safflower found that these nano-particles had differing effects on plant growth and quantitative and qualitative aspects of seed yield, and that the concentration of the nano-particles played largely contributed to these differences. Results revealed that, water-deficit stress drastically reduced the seed yield and seed oil content, while increasing the seed protein percentage. For almost all evaluated traits, the best performance was recorded under well irrigated 
condition with spraying low concentrations of nanoparticles. Under water-deficit stress, however, the differences between foliar treatments were not significant.Our study suggests that, foliar application of
$\mathrm{SiO}_{2}$ suspension at low concentration can be a suitable agronomic monument for improving safflower performance.

\section{REFERENCES}

Asadzade, N., Moosavi, S. G., Seghatoleslami, M. J. (2015). Effect of low irrigation and $\mathrm{Zn}$ and $\mathrm{SiO}_{2}$ nano-fertilizers and conventional fertilizers on morphophysiological traits and seed yield of sunflower. Biological Forum, 7(1), 357-364.

Asli, S., Neumann, P.M. (2009). Colloidal suspensions of clay or titanium dioxide nanoparticles can inhibit leaf growth and transpiration via physical effects on root water transport. Plant, Cell \& Environment, 32, 577-584. doi:10.1111/j.13653040.2009.01952.x

Darinkaboud, B. A., GharibiAsl, S. (2016). The oil and protein content of Isfahahn's safflower seed in different periods of irrigation, levels of humic acid and superabsorbent. International Journal of Life Sciences and Pharma Research, Special Issue, 5663.

Eneji, A. E., Inanaga, S., Muranaka, S., Li, J., Hattori, T., An, P., Tsuji, W. (2008). Growth and nutrient use in four grasses under drought stress as mediated by silicon fertilisers. Journal of Plant Nutrition, 31, 355-365. doi:10.1080/01904160801894913

Fatichi, S., Leuzinger, S., Körner, C. (2014). Moving beyond photosynthesis: from carbon source to sink-driven vegetation modeling. New Phytologist, 201(4), 1086-1095. doi:10.1111/nph.12614

Fauteux, F., Remus-Borel, W., Menzies, J. G., Bélanger, R. R. (2005). Silicon and plant disease resistance against pathogenic fungi. FEMS Microbiology Letter, 249, 1-6. doi:10.1016/j.femsle.2005.06.034

Frazier, T. P., Burklew, C. E., Zhang, B. (2013). Titanium dioxide nanoparticles affect the growth and microRNA expression of tobacco (Nicotiana tabacum). Functional \& Integrative Genomics, Available online, doi:10.1007/s10142-013-0341-4

Haghighati-Malek, A., Ferri, F. (2014). Effects of nitrogen and phosphorus fertilizers on safflower yield in dry lands condition. International Journal of Research in Agricultural Sciences, 1, 2348-3997.

Hattori, T., Inanaga, H., Araki, H., An, P., Morita, S., Luxova, M., Lux A. (2005). Application of silicon enhanced drought tolerance in Sorghum bicolor. Physiologia Plantarum, 123, 459-466. doi:10.1111/j.1399-3054.2005.00481.x
Hong, F., Zhou, J., Liu, C., Yang, F., Wu, C., Zheng, L., Yang, P. (2005). Effect of nano-TiO ${ }_{2}$ on photochemical reaction of chloroplasts of spinach. Biological Trace Element Research, 105 (1-3), 269279. doi:10.1385/BTER:105:1-3:269

Hussain, M. I., Lyra, D. A., Farooq, M., Nikoloudakis, N., Khalid, N. (2016). Salt and drought stresses in safflower: a review. Agronomy for Sustainable Development, 36 (1), 4-13. doi:10.1007/s13593015-0344-8

Janmohammadi, M., Amanzadeh, T., Sabaghnia, N., Dashti, S. (2016a). Impact of foliar application of nano micronutrient fertilizers and titanium dioxide nanoparticles on the growth and yield components of barley under supplemental irrigation. Acta Agriculturae Slovenica, 107(2), 265-276. doi:10.14720/aas.2016.107.2.23

Janmohammadi, M., Amanzadeh, T., Sabaghnia, N., Ion, V. (2016b). Effect of nano-silicon foliar application on safflower growth under organic and inorganic fertilizer regimes. Botanica Lithuanica, 22(1), 53-64. doi: doi:10.1515/botlit-2016-0005

Karimi, J., Mohsenzadeh, S. (2016). Effects of silicon oxide nanoparticles on growth and physiology of wheat seedlings. Russian Journal of Plant Physiology, 63(1), 119-123. doi:10.1134/S1021443716010106

Kaya, C., Tuna, L., Higgs, D. (2006). Effect of silicon on plant growth and mineral nutrition of maize grown under water-stress conditions. Journal of Plant Nutrition, 29(8), 1469-1480. doi:10.1080/01904160600837238

Khot, L. R., Sankaran, S., Maja, J. M., Ehsani, R., Schuster, E. W. (2012). Applications of nanomaterials in agricultural production and crop protection: a review. Crop Protection, 35, 64-70. doi:10.1016/j.cropro.2012.01.007

Lei, Z., Mingyu, S., Xiao, W., Chao, L., Chunxiang, Q., Liang, C., Fashui, H. (2007). Effects of nanoanatase on spectral characteristics and distribution of LHCII on the thylakoid membranes of spinach. Biological Trace Element Research, 120 (1-3), 273283. doi:10.1007/s12011-007-8025-3

Lei Z., Mingyu S., Xiao W., Chao L., Chunxiang Q., Liang C., Hao H, Xiaoqing L, Fashui, H. 2008. 
Antioxidant stress is promoted by nano-anatase in spinach chloroplasts under UV-B radiation. Biological Trace Element Research, 121(1), 69-79. doi:10.1007/s12011-007-8028-0

Liu, R., Lal, R. (2015). Potentials of engineered nanoparticles as fertilizers for increasing agronomic productions. Science of the Total Environment, 514, 131-139. doi:10.1016/j.scitotenv.2015.01.104

Ma, J. F., Miyake, Y., Takahashi, E. 2001. Silicon as a beneficial element for crop plants, in Silicon in Agriculture, (Eds.) New York, NY: Elsevier Science Publishing, 17-39. doi:10.1016/S09283420(01)80006-9

Ma, J. F., Yamaji, N. (2006). Silicon uptake and accumulation in higher plants. Trends in Plant Science, 11(8), 392-397. doi:10.1016/j.tplants.2006.06.007

Ma, J.F. (2004). Role of silicon in enhancing the resistance of plants to biotic and abiotic stresses. Soil Science and Plant Nutrition, 50, 11-18. doi: 10.1080/00380768.2004.

Mandeh, M., Omidi, M., Rahaie, M. (2012). In vitro influences of $\mathrm{TiO}_{2}$ nanoparticles on barley (Hordeum vulgareL.) tissue culture. Biological trace element research, 150(1-3), 376-380. doi:10.1007/s12011-012-9480-z

Mastronardi, E., Tsae, P., Zhang, X., Monreal, C., DeRosa, M. C. (2015). Strategic role of nanotechnology in fertilizers: potential and limitations. In Nanotechnologies in Food and Agriculture (pp. 25-67). Springer International Publishing. Switzerland, Cham. doi:10.1007/978-3319-14024-7_2

Morteza, E., Moaveni, P., Farahani, H. A., Kiyani, M. (2013). Study of photosynthetic pigments changes of maize (Zea mays L.) under nano Tio2 spraying at various growth stages. SpringerPlus, 2(1), 1-5. doi.10.1186/2193-1801-2-247

Murungweni, C., Wijk, M. T., Smaling, E. M. A., Giller, K. E. (2016). Climate-smart crop production in semi-arid areas through increased knowledge of varieties, environment and management factors. Nutrient Cycling in Agroecosystems, 105(3), 183197. doi:10.1007/s10705-015-9695-4

Pei, Z.F., Ming, D. F., Liu, D., Wan, G. L., Geng, X. X., Gong H. J., Zhou, W. J. (2010). Silicon improves the tolerance of water-deficit stress induced by polyethylene glycol in wheat (Triticum aestivum L.) seedlings. Journal of Plant Growth Regulation, 29, 106-115. doi:10.1007/s00344-009-9120-9
Pessarakli, M. (2014). Handbook of plant and crop physiology. CRC Press. United State, Florida.

Rudolphi, S., Becker, H. C., Schierholt, A., von WitzkeEhbrecht, S. (2012). Improved estimation of oil, linoleic and oleic acid and seed hull fractions in safflower by NIRS. Journal of the American Oil Chemists' Society, 89(3), 363-369. doi:10.1007/s11746-011-1920-y

Sahebi, M., Hanafi, M. M., Siti Nor Akmar, A., Rafii, M. Y., Azizi, P., Tengoua, F., Mayzaitul Azwa, F., Shabanimofrad, M. (2015). Importance of silicon and mechanisms of bio-silica formation in plants. BioMed research international, 1-16. doi:10.1155/2015/396010

Sabaghnia, N., Ahadnezhad, A., Janmohammdi, M. (2015). Genetic variation in garden cress (Lepidium sativum L.) germplasm as assessed by some morphological traits. Genetic Resources and Crop Evolution, 5(62): 733-745. doi:10.1007/s10722014-0192-4

Sangakkara, H. R., Hartwig, U. A., Nosberger, J. (1996). Response of root branching and shoot water potential of Phaeseolus valgaris L. to soil moisture and fertilizer potassium. Journal of Agronomy and Crop Science, 177, 165-173. doi:10.1111/j.1439037X.1996.tb00234.x

Shahrokhnia, M. H., Sepaskhah, A. R. (2017). Physiologic and agronomic traits in safflower under various irrigation strategies, planting methods and nitrogen fertilization. Industrial Crops and Products, $\quad 95$, 126-139. doi:10.1016/j.indcrop.2016.10.021

Shi, Y., Zhang, Y., Han, W., Feng, R., Hu, Y., Guo, J., Gong, H. (2016). Silicon Enhances Water Stress Tolerance by Improving Root Hydraulic Conductance in Solanum lycopersicum L. Frontiers in plant science, 7. doi:10.3389/fpls.2016.00196

UN (United Nations Department of Economic and Social Affairs, Population Division), (2013). World Population Prospects: the 2012 Revision.

Yang, F., Hong, F., You, W., Liu C., Gao, F., Wu, C., Yang, P. (2006). Influence of nano-anatase $\mathrm{TiO}_{2}$ on the nitrogen metabolism of growing spinach. Biological Trace Element Research, 110 (2), 179190. doi:10.1385/BTER:110:2:179

Zheng, L., Hong, F., Lu, S., Liu, C. (2005). Effect of nano- $\mathrm{TiO}_{2}$ on strength of naturally aged seeds and growth of spinach. Biological Trace Element Research. $104, \quad 83 \mathrm{e} 91$. doi:10.1385/BTER:104:1:083 